but I do not see that the fact has any hostile significance as regards the question of identity.

He will also find that I have always hitherto included the connecting medium as one of the "bodies" between which actions and reactions occur. (See for instance, Phil. Mag., June 1885, pp. $483^{-84}$, and October 1879, p. 281). I do not propose to continue to do this in future, partly because I find that the word "body" is not generally or conveniently understood to mean ether as well as ordinary matter, and partly because I now realise that there is something more definite to say concerning the function of the ether as regards stress.

But Mr. Dixon seems to suppose that the denial of action at a distance means that material particles are without influence on one another until they touch; that for instance the earth cannot attract the moon unless it is in contact with it ; for he says that my contention that material particles never come into contact renders nugatory the whole discussion inncerning "contact action."

If this be the sort of meaning which he attaches to the phrase "action at a distance," no wonder he is unimpressed with the arguments of those who deny its prevalence in nature.

Oliver LODGE.

MAY I make a few corrections of statements which appear in your report of Prof. Lodge's paper on the Laws of Motion (NATURE, p. II T)?

(I) I do not object to the first law on the ground of unintelligibleness, but only to the ordinary mode of enunciating it.

(2) I have not contended that Dr. Lodge's definition of energy as the name given to work done assumes conservation. On the contrary, I have expressly pointed out that it does not.

(3) I did not select the air-gun with its muzzle plugged as an instance of transference of potential energy without transformation. Prof. Lodge had cited the air-gun as an instance of the transformation of Potential Energy into kinetic during transference. I stated that if the muzzle were plugged it would serve equally well as an instance of the transference of potential energy without transformation. But I pointed out that both illustrations were defective and proceeded to show that in general the transformation of energy during transference is onlv partial.

Hop eville, Bridge of Allan, N.B., June 5 T. G. MACGREGOR.

\section{The Word Eudiometer.}

THE following quotation from T. A. Scherer's "Geschichte der Luftgütepriufungslehre" (Vienna, I 785), may be of interest in connection with Prof. McLeod's letter on the invention of the word "Eudiometer" (NATURE, vol. xlvii. p. 536). After referring to Fontana's Descrizione ed usi di alcuni stromenti per misurare la salubrità dell' aria "(Florence, I 775), Scherer continues (op. cit., vol. i. p. 153), "Bald nach der Herausgahe der gedachten Instrumente machte $\mathrm{Hr}$. Landriani ein neues bekannt, der erste, der es Eudiometer nannte. Er versichert uns er habe seinen Lufteiitemesser von Abt Fontana nicht entlehnt. Daher gehört die Ehre der Reformation des Priestley'schen Instruments Hrn. Landriani, die ihm auch Fontana selbst in zwei Briefen einräumt."

Landriani's own statement quoted by Prof. McLeod is thus fully confirmed by contemporary authority. Scherer's book, which has just been purchased for the Owens College from the Kopp library, is full of interesting historical information with regard to eudiometrv.

Owens College, May 23.

\section{Singular Swarms of Flies.}

Mr. Froude's letter (p. 103) forcibly reminds me of a swarm of flies which overlaid every one who was on the parade at Ventnor, and drove numbers $\mathrm{nff}$ the pier on the forenoon of a day which certainly fell on or between May I 3 and $\mathbf{r} 6,189 \mathrm{I}$. My diary bears only witness to the fact that I was then at Ventnor, but I shall never forget that as I went towards the black clouds I met a venerable friend, whose white hair, beard, and light coat were literally blackened with flies. The natives, who had had previous experience of such a cloud, ascribed it to the " mackerel fly." Mycolleagues in the entomological department of the British Museum told me I had witnessed a flight of Bibio Marci (St. Nark's fly), and, on reading up the subject, I found no reason to doubt that they had made an accurate diagnosis of a slightly and imperfectly told story.

NO. I 232 , voL. 48$]$
I have a definite recollection of the flies' rapid disappearance, and I have very little doubt that Mr. Froude has been the witness of a cloud of the same dipterous insect. . F. JEFFREY BELL.

5, Radnor Place, Gloucester Square, W., June 2.

P.S. - The weather was very warm during the days mentioned, but the succeeding (Whit) Monday was marked by a fall of snow in several parts of England. Absit omen! I add this as I note that Mr. Froude suggestsithat the special character of the swarms may have some relation to "some condition of the atmosphere."

THE phenomenon so well and exactly described by your correspondent, Mr. R. E. Froude (NATURE, vol. xlviii. p. 103) was seen the same day and hour-that is, between I and I. 30 , May 27-at Parkstone, near Poole, Dorset. A party which had driven over from my house, and lunched at the Harbour Hotel, saw every tree-top crowned, as it were, with a smoke-like column of flies, every column with the same slant one way, described by Mr. Froude, only it was not noticed that this was towards the sun. The strange sight was described to me by my daughter, by word and pencil, last Saturday, immediately on reaching home, and confirmed by her companions.

Bregner, Bournemouth, June 3.

\section{THE ANNUAL VISITATION OF THE} GREENWICH OBSERVATORY.

$A \mathrm{~T}$ the Annual Visitation of this Observatory, which A took place on Saturday, June 3 last, the Astronomer Royal presentea his report to the Board of Visitors.

The present want of accommodation is felt in all the departments of the Observatory, a number of the staff being at present boused in the Octagon room, which forms part of the Astronomer Royal's official residence. The Admiralty have now authorised the completion of the central octagon by the addition of a story and the erection of the Lassell dome over it.

In place of the old cylindrical dome on the south-east tower, which was dismounted in November last, the new 36-foot dome was erected at the beginning of the year, the work of construction and erection being completed most satisfactorily by Messrs. T. Cooke and Sons.

The electric light installation for the principal instruments proposed last year has been sanctioned, and the necessary generating plant, consisting of gas-engine, dynamo, accumulators, and main leads, has been supplied. It is proposed to set these up on the ground floor of the new south wing.

Referring now to the astronomical observations, the work of observing the sun, moon, planets, and fundamental stars with the transit circle has been considerably increased, owing to the extraordinarily fine weather in the months of March and April, the number of observations being the largest ever recorded. The numerical statement is as follows:-

Transits, the separate limbs being counted as separate observations $\ldots \quad \ldots \quad \ldots \quad \ldots$

Determinations of collimation error $\quad \ldots .304$

$\begin{array}{llll}\text { Determinations of level error } & \ldots & \ldots & 512\end{array}$

$\begin{array}{lllllll}\text { Circle observations } & \ldots & \ldots & \ldots & \ldots & 7179\end{array}$

Determinations of nadir point (included in

the number of circle observations) $\ldots$
Reflexion observations of stars (similariy

$$
\begin{array}{llllllll}
\text { included) } & \ldots & \ldots & \ldots & \ldots & \ldots & 527
\end{array}
$$

The annual catalogue of stars observed in 1892 contains 17 10 stars.

The report goes on to say:-

As an illustration of the continuity of fine weather in March and April, it may be mentioned that 2600 transits and 2300 circle observations were made in these two months, the average corresponding numbers for the seven previous years being 945 and 877 respectively; that 70 observations of upper and lower culminations of Polaris were obtained (exclusive of isolated observations, which are only used for azimuth error and not for place of the star), the average for these months in ten years 